\title{
Pigeonpea (Cajanus cajan L.) + Sesame (Sesamum indicum L.) Intercropping System under Variable Crop Geometry and Row Ratios under Rainfed Condition
}

\author{
P. B. Kale, N. G. Kurhade and S. U. Pawar* \\ Department of Agronomy, College of Agriculture, VNMKV, Parbhani, (M.S), India \\ *Corresponding author
}

\section{A B S T R A C T}

A field experiment was conducted at the experimental farm, Department of Agronomy, College of Agriculture, Vasantrao Naik Marathwada Krishi Vidyapeeth, Parbhani (M.S. during Kharif 2018 entitled to study the performance of pigeonpea + sesame intercropping system under variable crop geometry and plant population under rainfed condition. The experiment was laid out in randomized block design. There were total eight treatments

\section{Keywords}

Economics, Intercropping, Plant geometry,

Pigeonpea, Sesame, Yield

Article Info

Accepted:

08 January 2020

Available Online:

10 February 2020 consisting three row spacing of pigeonpea combined with 2 intra-row spacings and two sole cropping treatments of pigeonpea and sesame each in the recommended spacing of respective crops added. The intercropping system of pigeonpea + sesame crops was tried with row proportion of $1: 1$ in $90 \mathrm{~cm} \mathrm{x} 30 \mathrm{~cm}, 90 \mathrm{~cm}$ x $45 \mathrm{~cm}, 120 \mathrm{~cm}$ x $30 \mathrm{~cm}, 120 \mathrm{~cm} \times$ $45 \mathrm{~cm}$ spacings and 1:2 in $150 \mathrm{~cm} \times 30 \mathrm{~cm}$ and $150 \mathrm{~cm} \times 45 \mathrm{~cm}$ planting geometry of pigeonpea. two treatments of sole pigeonpea and sesame at $90 \mathrm{~cm}$ x $20 \mathrm{~cm}$ and $45 \mathrm{~cm} \times 15$ $\mathrm{cm}$ respectively. Inter row and intra row spacing of sesame in intercropping treatments were $45 \mathrm{~cm} \mathrm{x} 15 \mathrm{~cm}$ in $\mathrm{T}_{1}$ and $\mathrm{T}_{2}, 60 \mathrm{~cm} \mathrm{x} 15 \mathrm{~cm}$ in $\mathrm{T}_{3}$ and $\mathrm{T}_{4}$ and $50 \mathrm{~cm} \mathrm{x} 15 \mathrm{~cm}$ in $\mathrm{T}_{4}$ and $\mathrm{T}_{5}$. These treatments were replicated thrice. Among all the treatments highest pigeonpea seed yield, straw yield and harvest index was recorded with sole pigeon pea and was followed by pigeon pea + sesame intercropping $T_{1}$ pigeonpea + sesame in $1: 1$ with pigeonpea at $90 \mathrm{~cm} \times 30 \mathrm{~cm}$ intercropped with sesame at $45 \times 15 \mathrm{~cm}$. The treatment $\mathrm{T}_{1}$ i.e. pigeonpea + sesame in 1:1 with pigeonpea at $90 \mathrm{~cm} \times 30 \mathrm{~cm}$ intercropped with sesame at $45 \times 15 \mathrm{~cm}$ also recorded highest pigeonpea equivalent yield (1943 $\mathrm{kg}$ ha- ${ }^{1}$ ), Land equivalent ratio, area time equivalent ratio, aggressivity which was followed by treatment $\mathrm{T}_{3}$ i.e. pigeonpea + sesame in $1: 1$ with pigeonpea at $120 \times 30 \mathrm{~cm}$ and sesame at $60 \times 15$ $\mathrm{cm}$ and $\mathrm{T}_{7}$ i.e. sole pigeonpea at spacing of $90 \mathrm{~cm} \times 20 \mathrm{~cm}$.

\section{Introduction}

The availability of land for agriculture is shrinking every day as it is increasingly utilized for non-agricultural purposes. Under this situation, one of the important strategies to increase agricultural output is the development of new high intensity cropping systems including intercropping system. India is the largest producer of pulses and oilseeds in the world and more than a dozen pulse and oilseed crops are grown in the country. Pulses 
which form a major source of dietary protein play a significant role in biological nitrogen fixation from the atmosphere and enrich the soil fertility. Similarly, oilseed crops are taking part in fulfilling the requirements of oil for human consumption and other purposes.

Intercropping, under rainfed ecosystem, ensures stability in yield and minimizes risk of crop loss due to aberrant weather condition. Therefore under rainfed condition where the chances of crop failure are more, intercropping is more stable and dependable than sole crops. The main advantage of the intercropping is that the component crops are able to use the growth resources differently and make better overall use of growth resources than the crops grown separately. Intercropping gives bonus yield under more favourable season besides the optimum yield of main crop.

Pigeonpea has compensatory behaviour in respect of plant population and crop geometry to economic yield. Pigeonpea based intercropping systems have proved sustainable in respect of yield and income with short duration intercrops of cereals, pulses and oilseed crop across diverse rainfed agro ecologies in India (Rao et al., 2003). In the scarcity zone of Maharashtra, pigeonpea is cultivated during kharif under diverse biophysical (soil and rainfall types) and socioeconomic settings, thus always risk prone due to in-season drought, particularly in shallow to medium black soils, abiotic factors often resulting in unsustainable yields and income.

Sesame is one of the most ancient crop grown particularly in semi-arid region of India. Yield potential of sesame can be exploited by the use of agronomic techniques. Among the standardized agronomic practices required for realizing yield potential of sesame, plant geometry and selection of variety are the most important factors in determining yield. The planting geometry helps in altering canopy architecture affecting light interception and $\mathrm{CO}_{2}$ assimilation which further affect the productivity. So spacing is important factor for altering the architecture to increase the production of sesame.

For achieving stable crop production and enhance yield insurance against aberrant weather condition as well as to mitigate abiotic stresses during growing period under rainfed agriculture, intercropping is one of the best agronomical option to minimize risk lead to farmer profit and subsistence oriented, energy efficient and sustainable venture (Faroda et al., 2007). Keeping the above facts in view, an experiment was undertaken to study the performance of pigeonpea (Cajanus cajan L.) + sesame (Sesamum indicum L.) intercropping system under variable crop geometry and population level under rainfed condition.

\section{Materials and Methods}

The field experiment was conducted during kharif season of 2018 at experimental farm, Department of Agronomy, Vasantrao Naik Marathwada Krishi Vidhyapeeth, Parbhani. Geographically, Location of the site is situated at $19^{\circ} 16^{\prime}$ North latitude and $76^{\circ} 47$ East longitudes and at 409 altitudes above sea level and has a semi-arid climate. The experimental soil was black soil having $\mathrm{pH}$ 8.3 , medium in organic carbon $(0.51 \%)$, low in available nitrogen ( $\mathrm{kg} / \mathrm{ha})$, medium in available phosphorus (kg/ha), medium in available $\mathrm{K}(\mathrm{kg} / \mathrm{ha})$ as determined by standard methods.

The experiment was laid out in RBD with 3 replications and 8 treatments There were total eight treatments consisting three row spacing of pigeonpea combined with 2 intra-row spacings and two sole cropping treatments of 
pigeonpea and sesame each $\mathrm{T}_{1} 90 \times 30 \mathrm{~cm}^{2}+$ $45 \times 15 \mathrm{~cm}^{2}(1: 1), \mathrm{T}_{2} 90 \times 45 \mathrm{~cm}^{2}+45 \times 15$ $\mathrm{cm}^{2}(1: 1), \mathrm{T}_{3} 120 \times 30 \mathrm{~cm}^{2}+60 \times 15 \mathrm{~cm}^{2}(1: 1)$, $\mathrm{T}_{4} 120 \times 45 \mathrm{~cm}^{2}+60 \times 15 \mathrm{~cm}^{2}(1: 1), \mathrm{T}_{5} 150 \mathrm{x}$ $30 \mathrm{~cm}^{2}+50 \times 15 \mathrm{~cm}^{2}(1: 2), \mathrm{T}_{6} 150 \times 45 \mathrm{~cm}^{2}+$ $50 \times 15 \mathrm{~cm}^{2}(1: 2), \mathrm{T}_{7}($ Sole pigeonpea $) 90 \mathrm{~cm} \mathrm{x}$ $20 \mathrm{~cm}, \mathrm{~T}_{8}$ Sole sesame at $45 \mathrm{~cm} \times 15 \mathrm{~cm}$. Recommended practices for plant protection were followed.

\section{Results and Discussion}

\section{Effect of treatments on Pigeonpea seed yield}

Pigeonpea seed yield (1827 kg ha $\left.{ }^{-1}\right)$ was substantially higher under dense planting geometry (Table 1) i.e. sole pigeonpea (90 $\mathrm{cm} \times 20 \mathrm{~cm})$ over pigeonpea + sesame intercropping systems with wider planting geometry i.e. $90 \times 45 \mathrm{~cm}^{2}, 120 \times 45 \mathrm{~cm}^{2}$ and $150 \times 30 \mathrm{~cm}^{2}$. Stalk yield and biological yield of pigeonpea showed similar trend as that of seed yield of pigeonpea. Increased plant population pressure which facilitated more uptakes of nutrients and soil moisture per unit area coupled with better interception of light which might have increased leaf area and leaf mass which resulted in better translocation of photosynthates which might have contributed towards the development of plant and finally increased pigeonpea seed yield $\left(\mathrm{kg} \mathrm{ha}{ }^{-1}\right)$. Advantages with dense planting geometry on pigeonpea yield was reported by Reddy et al., (1993), Sonawane et al., (2011) and Rathod et al., (2004 a).

Effect of treatments on pigeonpea equivalent yield, Land equivalent ratio (LER), Area time equivalent ratio (ATER) and Aggressivity

Pigeonpea equivalent yield differed markedly among the treatments comprising of planting geometry adapted to pigeonpea and proportions of pigeonpea and sesame.
Significantly higher pigeonpea equivalent yield $\left(1943 \mathrm{~kg} \mathrm{ha}^{-1}\right)$ was obtained in narrow planting geometry of pigeonpea + sesame intercropping with pigeonpea at $90 \mathrm{~cm} \times 30$ $\mathrm{cm}$ and sesame at $45 \mathrm{~cm} \mathrm{x} 15 \mathrm{~cm}$. The higher pigeonpea yield may have attributed to to higher pigeonpea equivalent yield. The results are in line with the findings of research by Goyal et al., (1991) and Singh and Singh (1994).

Land equivalent ratio (LER) (Table 2) differed significantly due to intercropping treatments. In general, all the intercropping treatments recorded higher LER values than sole cropping treatments. Highest LER was recorded when sesame intercropped with pigeonpea in $(90 \mathrm{~cm} \times 30 \mathrm{~cm}+45 \mathrm{~cm} \times 15$ $\mathrm{cm}$ ) in 1:1 row proportion followed by planting geometry $150 \mathrm{~cm} \mathrm{x} 30 \mathrm{~cm}+50 \mathrm{~cm} \mathrm{x}$ $15 \mathrm{~cm}$ ) with 1:2 row proportion. Higher LER values in the above mentioned intercropped treatments were due to higher yield of component crops in relation to their sole crops. This was evident by higher combined seed yield per plant of both the crops per unit area. The higher combined seed yield could intern related to the fact that component crops differed in utilization of growth resources and converting them more efficiently into yield components resulting in higher yield per plant and yield per unit area. Similar results obtained from Singh and Singh (1994) and Narkhede and Katare (1998).

Area time equivalent ratio (ATER) differed significantly due to intercropping treatments comprising of planting geometry and row spacings. The significantly higher ATER was recorded when sesame intercropped with pigeonpea in $(90 \mathrm{~cm} \times 30 \mathrm{~cm}+45 \mathrm{~cm} \times 15$ $\mathrm{cm}$ ) in 1:1 row proportion followed by planting geometry $(90 \mathrm{~cm} \times 20 \mathrm{~cm})$. Lowest ATER was recorded in sole sesame $(45 \mathrm{~cm} \times$ $15 \mathrm{~cm})$ (0.671). Higher ATER values in the above mentioned intercropped treatments 
were due to higher combined seed yield per plant of both the crops per unit area and longer duration of the crop present on the land from planting to harvest. These results are with agreement in the research findings of Pujari (1996).

Table.1 Seed yield $\left(\mathrm{kg} \mathrm{ha}^{-1}\right)$, straw yield $\left(\mathrm{kg} \mathrm{ha}^{-1}\right)$, biological yield $(\mathrm{kg}$ $\mathrm{ha}^{-1}$ ) and harvest index (HI) (\%) of pigeonpea as influenced by different treatments

\begin{tabular}{|c|c|c|c|c|c|c|}
\hline $\begin{array}{l}\text { Trt } \\
\text { No. }\end{array}$ & $\begin{array}{c}\text { Treatments } \\
\text { Pigeonpea + Sesame }\end{array}$ & $\mathbf{R P}$ & $\begin{array}{c}\text { Seed } \\
\text { yield } \\
\left(\mathrm{kg} \mathrm{ha}^{-1}\right)\end{array}$ & $\begin{array}{c}\text { Straw } \\
\text { yield } \\
\left(\mathrm{kg} \mathrm{ha}^{-1}\right)\end{array}$ & $\begin{array}{c}\text { Biologic } \\
\text { al yield } \\
\left(\mathrm{kg} \mathrm{ha}^{-1}\right)\end{array}$ & $\begin{array}{c}\text { Harvest } \\
\text { index } \\
(\%)\end{array}$ \\
\hline$T_{1}$ & $90 \times 30 \mathrm{~cm}^{2}+45 \times 15 \mathrm{~cm}^{2}$ & $(1: 1)$ & 1610 & 5112 & 6722 & 23.95 \\
\hline $\mathbf{T}_{2}$ & $90 \times 45 \mathrm{~cm}^{2}+45 \times 15 \mathrm{~cm}^{2}$ & $(1: 1)$ & 1296 & 4403 & 5699 & 22.74 \\
\hline $\mathbf{T}_{3}$ & $120 \times 30 \mathrm{~cm}^{2}+60 \times 15 \mathrm{~cm}^{2}$ & $(1: 1)$ & 1529 & 4944 & 6473 & 23.62 \\
\hline $\mathbf{T}_{4}$ & $120 \times 45 \mathrm{~cm}^{2}+60 \times 15 \mathrm{~cm}^{2}$ & $(1: 1)$ & 1139 & 3747 & 4886 & 23.31 \\
\hline $\mathbf{T}_{5}$ & $150 \times 30 \mathrm{~cm}^{2}+50 \times 15 \mathrm{~cm}^{2}$ & $(1: 2)$ & 1170 & 3930 & 5100 & 22.94 \\
\hline$T_{6}$ & $150 \times 45 \mathrm{~cm}^{2}+50 \times 15 \mathrm{~cm}^{2}$ & $(1: 2)$ & 976 & 3369 & 4345 & 22.46 \\
\hline $\mathbf{T}_{7}$ & $\begin{array}{l}\text { (Sole pigeonpea) } \\
90 \mathrm{~cm} \text { x } 20 \mathrm{~cm}\end{array}$ & -- & 1827 & 5677 & 7504 & 24.34 \\
\hline $\mathbf{T}_{8}$ & $\begin{array}{l}\text { ( Sole sesame) } \\
45 \mathrm{~cm} \times 15 \mathrm{~cm}\end{array}$ & -- & -- & -- & -- & -- \\
\hline & $\operatorname{SE}(m) \pm$ & -- & 75.42 & 180.70 & 218 & -- \\
\hline & CD at $5 \%$ & -- & 232.38 & 557.02 & 671 & -- \\
\hline & General mean & -- & 1363 & 4454 & 5818 & 23.33 \\
\hline
\end{tabular}

Table.2 Pigeonpea equivalent yield (PEY) and Land equivalent ratio (LER), Area time equivalent ratio (ATER), Aggressivity under different row proportions as influenced by different treatments

\begin{tabular}{|c|c|c|c|c|c|c|}
\hline $\begin{array}{c}\text { Trt. } \\
\text { No }\end{array}$ & $\begin{array}{c}\text { Treatment } \\
\text { Pigeonpea + Sesame }\end{array}$ & RP & $\begin{array}{c}\text { PEY } \\
(\mathbf{k g} / \mathbf{h a})\end{array}$ & LER & ATER & Aggresivity \\
\hline $\mathbf{T}_{\mathbf{1}}$ & $90 \times 30 \mathrm{~cm}^{2}+45 \times 15 \mathrm{~cm}^{2}$ & $(1: 1)$ & 1943 & 1.40 & 1.136 & 0.716 \\
\hline $\mathbf{T}_{\mathbf{2}}$ & $90 \times 45 \mathrm{~cm}^{2}+45 \times 15 \mathrm{~cm}^{2}$ & $(1: 1)$ & 1664 & 1.28 & 0.991 & 0.261 \\
\hline $\mathbf{T}_{\mathbf{3}}$ & $120 \times 30 \mathrm{~cm}^{2}+60 \times 15 \mathrm{~cm}^{2}$ & $(1: 1)$ & 1764 & 1.20 & 1.017 & 0.935 \\
\hline $\mathbf{T}_{\mathbf{4}}$ & $120 \times 45 \mathrm{~cm}^{2}+60 \times 15 \mathrm{~cm}^{2}$ & $(1: 1)$ & 1403 & 1.03 & 0.826 & 0.415 \\
\hline $\mathbf{T}_{\mathbf{5}}$ & $150 \times 30 \mathrm{~cm}^{2}+50 \times 15 \mathrm{~cm}^{2}$ & $(1: 2)$ & 1584 & 1.29 & 0.958 & 0.944 \\
\hline $\mathbf{T}_{\mathbf{6}}$ & $150 \times 45 \mathrm{~cm}^{2}+50 \times 15 \mathrm{~cm}^{2}$ & $(1: 2)$ & 1432 & 1.25 & 0.884 & 0.526 \\
\hline $\mathbf{T}_{\mathbf{7}}$ & $($ Sole pigeonpea $)$ & -- & 1827 & 1 & 1 & -- \\
\hline & $90 \mathrm{~cm}^{2} 20 \mathrm{~cm}$ & -- & 635 & 1 & 0.671 & -- \\
\hline $\mathbf{T}_{\mathbf{8}}$ & $\begin{array}{c}\text { ( Sole sesame) } \\
45 \mathrm{~cm} \times 15 \mathrm{~cm}\end{array}$ & -- & 90.09 & -- & -- & -- \\
\hline & SE $(\mathbf{m}) \pm$ & -- & 273.2 & -- & -- & -- \\
\hline & CD at 5\% & -- & $\mathbf{1 5 3 1}$ & $\mathbf{1 . 1 8}$ & $\mathbf{0 . 9 3 5}$ & $\mathbf{0 . 6 3 2}$ \\
\hline
\end{tabular}


Aggressivity differed significantly due to intercropping treatments comprising of planting geometry and row spacings. In general, all the intercropping treatments recorded positive aggressivity values. The significantly higher aggressivity was recorded when sesame intercropped with pigeonpea in $(150 \mathrm{~cm} \times 30 \mathrm{~cm}+50 \mathrm{~cm} \times 15 \mathrm{~cm})$ in $1: 2$ row proportion followed by planting geometry $(120 \mathrm{~cm} \times 30 \mathrm{~cm}+60 \mathrm{~cm} \times 15 \mathrm{~cm})$. Higher aggressivity values in the above mentioned intercropped treatments were due to relative yield increase in one component was greater than that for other component.

From the result, it can be concluded that, pigeonpea + sesame intercropping with pigeonpea at $90 \times 30 \mathrm{~cm}^{2}$ and sesame at $45 \mathrm{x}$ $15 \mathrm{~cm}^{2}$ in $1: 1$ row ratio was found to be productive and profitable as compared with other plant geometry and row ratios.

\section{References}

Goyal, S. N., Patel, N. L., Patel, N. M. and Ahlawat, R. P. S., 1991, Intercropping studies in pigeonpea under rainfed conditions. Indian J. Agron., 36(1): 4951 .

Hirwe, N.A. and H.S. Mahajan. 2012. Performance of sesamum + pigeonpea intercropping system on farmer's field. Agric.Update, 7(3\&4): 369-371.

Kondap, S. M., Rao, A. R., Mirza, W. A. and Bhojireddy, G., 1985, Intercropping with legumes. J. Oilseeds Res., 2: 124-
128.

Narkhede, W. N. and Katare, R. A., 1998, Studies on pigeonpea and sesame intercropping system. J. Maharashtra Agric. Univ., 23: 330-331.

Prajapat, K., A.C. Shivran, G.L. Choudhary and S. Kumawat 2012. Growth and productivity of sesame (Sesamum indicum) as influenced by intercropping with mungbean (Vigna radiata) and sulphur fertilization . Annual agric. Res. New Series Vol. 33 (1 and 2): 84- 87.

Pujari, B.T. 1996, Pigeonpea based intercropping system in Vertisols of North Eastern Dry Zone of Karnataka. Ph.D.Thesis, Univ. of Agric. Sci., Dharwad, Karnataka, India.

Rathod, P.S., S.I. Halikatti, S.M. Hiremath and S.T. Kajjidoni. 2004. Influence of different intercrops and row proportions on yield and yield parameters of pigeonpea in Vertisols of Dharwad. Karnataka Journal of Agriculture Science. 17: 652-657.

Singh, R. A. and Singh, A. K., 1994, Comparative performance of different intercropping systems with pigeonpea under rainfed conditions of Vindhya region. Indian J. Agron., 39(4): 613615.

Sonawane, D.A., V.M. Bahale and N.D. Dalavi. 2011. Evaluation of pigeonpea based intercropping systems under scarcity condition of Northern Maharashtra. JNKVV Research Journal. 45(1): 81-84.

\section{How to cite this article:}

Kale, P. B., N. G. Kurhade and Pawar, S. U. 2020. Pigeonpea (Cajanus cajan L.) + Sesame (Sesamum indicum L.) Intercropping System under Variable Crop Geometry and Row Ratios under Rainfed Condition. Int.J.Curr.Microbiol.App.Sci. 9(02): 821-825.

doi: https://doi.org/10.20546/ijcmas.2020.902.099 